\title{
PROTOTIPNI MODELI V SISTEMU GEOINFORMACIJSKE INFRASTRUKTURE
}

\author{
Matjaž Hribar
}

Izvleček

UDK 91:681.3

Vsebina je razdeljena $v$ štiri dele:

1. Kratko so predstauljene teoretične osnove s področja GIS (velika količina podatkov, kompatibilnost podatkov, informacijski standardi, definicija GIS, itd.).

2. Opisani so razlogi za pristop $k$ izdelavi prototipnih modelov geoinformacijske infrastrukture (GI).

3. Predstavljeni so prototipni modeli $v$ sistemu geoinformacijske infrastrukture (zemljiški kataster, kataster zgradb, relief).

4. Opisano je nadaljevanje projektov.

Abstract

UDC $91: 681.3$

THE PROTOTYPE MODELS IN THE SYSTEM OF GEOINFORMATIC INFRASTRUCTURE

The contents is divided into four parts:

1. Theoretical bases in the field of GIS are briefly presented (great amount of data, data compatibility, information standards, GIS definition, etc.).

2. Reasons for elaboration of geoinformational infrastructure prototype models are described.

3. Prototype models in a system of geoinformation infrastructure (land cadastre, cadastre of buildings, relief) are presented.

4. Continuation of the projects is described.

\section{TEORETIČNE OSNOVE}

Kvalitetne podatke o prostoru rabimo danes bolj kot kdaj koli. Pravočasen dostop do kvalitetnih podatkov je mogoč le, če vsakdo na svojem področju zbira in vzdržuje vse relevantne podatke tako, da so le-ti hitro in enostavno dosegljivi njemu samemu in vsem, ki se zanje zanimajo in imajo pravico do njihove uporabe. Seveda brez vse večjega uveljavljanja računalniške tehnologije in uvajanja le-te $v$ naše okolje ne gre.

Mag. Matjaž Hribar, HEUREKA IGEA, d.o.o, Koprska 94, 61000 Ljubljana 
Ko govorimo o podatkih, ki se nanašajo na prostor, govorimo o ogromnih količinah podatkov, ki so potrebni in interesantni za vse nivoje odločanja.

Najvažnejši kriterij, ki vpliva na dosegljivost podatkov in s tem na učinkovitost dela je možnost njihove medsebojne izmenljivosti (kompatibilnost podatkov). To pa ne pomeni, da morajo biti vse baze podatkov zgrajene popolnoma unificirano, ampak da pri vzpostavljanju upoštevamo svetovne standarde na področju informatike na eni strani in dogovorjene vsebinske standarde po posameznih tematikah na drugi strani.

Informacijski standardi so na osnovi svetovnih izkušenj znani, vsebinski pa so odvisni predvsem od posameznih strok, ki so pristojne za določeno vsebino. Podobno kot so se že izoblikovali standardi za strojno opremo v povratni - feed back povezavi med proizvajalci in končnimi uporabniki, tako se tudi na področju sistemov za obdelavo prostorskih podatkov tudi pri nas že pojavljajo standardi, ki so sad podobnega sodelovanja med proizvajalci in uporabniki in delno tudi načrtno usmerjenega pristopa s strani države. To je tudi edina pot do kvalitetnih vsebinskih standardov.

V svetu je že preverjeno dejstvo, da so Geografski Informacijski Sistemi in $s$ tem GIS tehnologija, s svojo naslonitvijo na s koordinatami (ali gridom) definiramo prostorsko lokacijo, tisto okolje, ki daje možnost obdelave velike količine podatkov in optimalne kompatibilnosti podatkov in komunikativnosti $\mathrm{z}$ in med uporabniki.

GIS so računalniško podprti prostorski informacijski sistemi za zajemanje, shranjevanje, iskanje, analiziranje, prikazovanje in distribucijo prostorskih podatkov in informacij.

Vsak GIS ima pet pomembnih komponent:

- ljudje,

- strojna oprema,

- programska oprema oz. zbirka programskih modulov (orodja),

- shranjeni strukturirani podatki (geografska baza podatkov, digitalna baza podatkov),

- organizacijski kontekst oz. postopki (aplikacije).

$\mathrm{Za}$ uspešno delovanje sistema in povezovanje mora biti prisotnih vseh pet komponent, poleg tega mora vsaka od teh komponent zadovoljevati že omenjene informacijske in vsebinske standarde.

Poglejmo si pobliže vsako od komponent:

Ljudje:

Sem spadajo načrtovalci, upravljalci, uporabniki.

Strojna oprema:

Najrazličnejša strojna oprema (osebni računalniki, delovne postaje, host računalniki, itd.). 


\section{Programska oprema:}

Napačno bi bilo, če ne bi želeli za svojo uporabo najbolj razširjenih in s tem po mnenju večine sveta najuporabnejših in primernih orodij, kot so ARC INFO, MGE, SPENS, GDC, itd. Na ta način pridobimo tudi dobršen del informacijskih standardov. Pri izbiri sistema ne sme igrati glavno vlogo cena, ampak kvaliteta, kajti orodja GIS predstavljajo le nekaj procentov v strukturi cene za vzpostavitev celotnega GIS-a, predstavljajo pa ogromen prihranek pri vzpostavljanju digitalne baze podatkov ( $v$ nadaljevanju DBP).

\section{Shranjeni strukturirani podatki:}

To je časovno, finančno in kadrovsko najbolj zahtevna komponenta (60\%), zato moramo poseben poudarek nameniti prav tej komponenti. Da je neka baza res grafična baza podatkov (v nadaljevanju GBP), mora izpolnjevati osnovne kriterije:

a) v GBP nastopata dve vrsti podatkov, integriranih v celoto:

- kartografski (lokacijski); točka, linija, poligon - koordinatno podani

- opisni (atributni);

b) lokacijski podatki so strukturirani tako, da omogočajo gradnjo topologije

in topološke kontrole - zapiranje poligonov (CAD sistemi)

c) atributne baze so praviloma relacijske (SQL baze)

\section{Organizacijski kontekst oz. postopki:}

To so aplikacije, ki omogočajo delovanje sistema (zajem, procesiranje, vpogledovalnik, vzdrževanje, distribuiranje podatkov).

Podrobneje bi želeli predstaviti še en pojem - tehnologija GIS.

Celoten prostor $\mathrm{v}$ okviru tehnologije oz. metodologije GIS razdelimo na poljubno število tematik oz. informacijskih slojev ( $v$ nadaljevanju IS). Nato naloge rešujemo tako, da kombiniramo potrebne stroke oz. njihove tematike - IS, podobno kot prosojnice, med seboj. Pri tem je potrebno poudariti, da ne manipuliramo le s slikami, ampak $z$ bazami podatkov, ki te slike podpirajo.

\section{RAZLOGI ZA PRISTOP K IZDELAVI PROTOTIPNIH MODELOV GEOINFORMACIJSKE INFRASTRUKTURE}

V državi Sloveniji se na področju zemljiških informacijskih sistemov (land information systems - LIS) oz. ustreznih digitalnih podatkovnih baz prostora, tako topografskih (relief, infrastrukturni objekti, zgradbe, hidrografija) kot na področju zemljiškega katastra (ZK) in katastra zgradb (KZ) operativno odvijajo aktivnosti $v$ občinah (pilotski projekti) in na državnem nivoju (projekt metodološko tehnoloških rešitev kot osnova za nastavitev zgornjih digitalnih baz podatkov). S temi dejavnostmi skušamo slediti, v skladu $\mathrm{z}$ našimi možnostmi, trenutnim svetovnim dogajanjem, kjer $\mathrm{v}$ to področje ogromno vlagajo (čas, kadri, denar, tehnologija). Poglaviten razlog za naša prizadevanja je to, da "cost benefit" analize kažejo, da je učin- 
kovitost sistemov upravljanja, odločanja, načrtovanja na vseh nivojih $z$ uvajanjem GIS tehnologije, ki temelji na zbranih digitalnih bazah, bistveno povečana.

Slovenija je hkrati $\mathrm{v}$ procesu prestrukturiranja družbene lastnine, kar ima za posledico tudi nastajanje novih lastninskih odnosov na zemljiščih in objektih. Za dosego tega cilja so potrebne obnovljene, računalniško podprte baze geoorientiranih podatkov, ki so bile $\mathrm{v}$ preživelem sistemu družbene lastnine zanemarjene.

Geoorientirani informacijski sistemi (GIS, LIS) so osnovani na kvalitetni geoinformacijski infrastrukturi, ki predstavlja geometrično oz. matematično osnovo prostora (digitalna baza zemljiškega katastra, kataster zgradb, relief, hidrografija, infrastruktura). Le ta služi za geolociranje vseh geoorientiranih podatkov in informacij.

V novih pogojih podatke o prostoru nujno rabijo številni uporabniki prostora, kot so planerji, upravljalci, urbanistični in ruristični projektanti. Njihovi projekti temeljijo na kmetijskih, gozdarskih, hidrografskih, splošnih geografskih, geoloških in drugih podatkih oz. sistemih. Osnova vsem tem sistemom in tudi mnogim drugim je geometrijski skelet oz. geometrija prostora. Ta omogoča vsem zgoraj omenjenim sistemom črpanje ustreznih podatkov in s tem zagotavlja njihovo operativnost in funkcioniranje.

\section{Stanje $v$ Sloveniji:}

Po obstoječi zakonodaji in praksi geokodirane podatke o geometriji prostora zagotavlja geodetska služba. Zatečeno stanje ne odgovarja novim potrebam oz. zgornjim usmeritvam. Geodetska služba trenutno še ne producira in ne distribuira potrebnih digitalnih prostorskih podatkovnih baz geoinformacijske infrastrukture.

\section{PROTOTIPNI MODELI V SISTEMU GEOINFORMACIJSKE INFRASTRUKTURE (zemljiški kataster, kataster zgradb, relief)}

Prav to opisano stanje je povzročilo razpis projekta "Kompjuterizacija evidenc v geodetskih službah" v oktobru 1991 z naslednjimi komponentami oz. podprojekti:

Metodološko tehnološke rešitve vzpostavitve in vzdrževanja digitalne baze:

- zemljiškega katastra,

- digitalne baze katastra zgradb,

- digitalne baze reliefa,

- digitalne baze hidrografije,

- digitalne baze infrastrukture.

Projekt je razpisalo ministrstvo za varstvo okolja in urejanje prostora (MVOUP). Projekt je v zaključni fazi, zgornje tehnološke rešitve so izdelane. 
Sem koordinator naslednjih treh prodprojektov, ki jih izvaja Heureka Igea v okviru zgornjega razpisa:

Metodološke in tehnološke rešitve za vzpostavitev in vzdrževanje:

- digitalne baze zemljiškega katastra, - digitalne baze katastra zgradb,

- digitalne baze reliefa (vključno $z$ mejnimi linijami infrastrukture in hidrografije).

Te tri digitalne baze predstavljajo skupaj $z$ digitalno bazo infrastrukture in hidrografije, ki se kot mejni liniji vključujeta $v$ digitalno bazo reliefa (nujno je torej vsklajeno polnenje digitalne baze reliefa, hidrografije, infrastrukture), matematično osnovo oz. geometrijo prostora, na katero se nato navezujejo vsi uporabniki prostora.

Pri projektu digitalne baze reliefa sodeluje MDS Metalka in INTERGRAPH Italija. Vsi trije projekti so že uspešno zaključeni, teče pa še njihovo ovrednotenje.

Projekti so razdeljeni v dve skupini:

Prva skupina:

omogoča predvsem povezavo na lastninsko komponento. Skupino sestavljata podprojekta za vzpostavitev in vzdrževanje digitalne baze zemljiškega katastra in digitalne baze katastra zgradb.

Druga skupina:

le-to tvorijo podprojekti, ki omogočajo povezavo na prostorsko komponento. To so podprojekti za vzpostavitev in vzdrževanje digitalne baze reliefa, digitalne baze infrastrukture in digitalne baze hidrografije.

Obe skupini se med seboj povezujeta in dopolnjujeta.

Šele digitalni zemljiški kataster omogoča izvajanje naslednih funkcij:

- vzpostavitev sodobnega fiskalnega katastra,

- preoblikovanje pravne funkcije zemljiškega katastra,

- oblikovanje informacijske funkcije zemljiškega katastra $\mathrm{v}$ povezavi $\mathrm{z}$ drugimi tematikami - informacijskimi sloji (layer),

- vzpostavitev enotne evidence nepremičnin,

- vzpostavitev osnove za modularno tehnološko obnovo zemljiškega katastra.

Ravno tako predstavlja digitalni zemljiški kataster osnovo za vzpostavitev digitalne baze katastra zgradb. 
Digitalna topografska karta (relief, infrastruktura, hidrografija, stavbe), predvsem $z$ digitalnim modelom reliefa, predstavlja važen element za modularno tehnološko obnovo zemljiškega katastra v smislu koordinatnega katastra, preko metode digitalnega ortofota.

\section{NADALJEVANJE PROJEKTOV}

Prve ocene so pokazale, da je že dosežen ter osvojen zadosten tehnološki nivo znanja, da so izbrani in osvojeni zadovoljivi podatkovni standardi, ter da je zbranih veliko praktičnih tehnoloških izkušenj na področju LIS, za izvedbo projektov na nivoju celotne Slovenije. Evalvacija še teče. Veliko dela nas čaka na organizacijski, managmentski in izobraževalni komponenti pri pripravi okolja za uspešno implementacijo novih tehnologij.

Podajam kratek pregled aktivnosti, ki morajo zagotoviti implementacijo omenjenih projektov. V prvi fazi je potrebno kompletirati obstoječe prototipne projekte vključno infrastrukturo in hidrografijo in opredeliti vlogo petih dodatnih tematik, ki so $\mathrm{v}$ tesni zvezi $\mathrm{z}$ njimi. To so:

- register območij teritorialnih enot (ROTE),

- evidenca hišnih številk (EHIŠ),

- geodetske točke,

- toponimi,

- pokrovnost - vegetacija.

Kot končen rezultat moramo dobiti naslednje predloge:

- predlog šifražnega sistema oz. predlog kodiranja,

- predlog standardov za zajemanje in transfer podatkov,

- predlog standardne proizvodnje linije za vzpostavitev LIS v konceptu distribuiranih baz podatkov,

- predlog osnovnih standardov za vzdrževanje digitalnih baz podatkov,

- predlog osnovnih standardov za kompletno računalniško poslovanje geodetskih uprav.

Na osnovi dokončno rešenih zgornjih tehnoloških vprašanj je potrebno podati predlog zakonskih in podzakonskih predpisov in programa geodetskih del za obdobje implementacije katastrsko podprtega LIS za Slovenijo.

Sledi priprava na implementacijo in implementacija vseh projektov $v$ Sloveniji $\cdot \mathrm{v}$ republiški center in regionalne ter lokalne centre. Intenzivne aktivnosti v tej smeri že tečejo.

Usklajeno $z$ zgornjimi prizadevanji, vendar $z$ lastnimi vlaganji in napori, podjetje Heureka Igea izvaja oz. pripravlja izvajanje pilotskih projektov v petih občinah (slika 1). Pilotske projekte bi lahko označili s skupnim naslovom "Vzpostavitev digitalne baze zemljiškega katastra kot dela zemljiške- 
ga informacijskega sistema regije oz. občine”. Ti predstavljajo idealno osnovo za testiranje nekaterih tehnoloških rešitev, sprejetih na državnem nivoju, v praksi in istočasno pomenijo operativne sisteme, ki bistveno povečajo kvaliteto poslovanja občinske geodetske uprave in tudi občine oz. regije kot celote.

Slika 1: Pilotski projekti v Sloveniji.

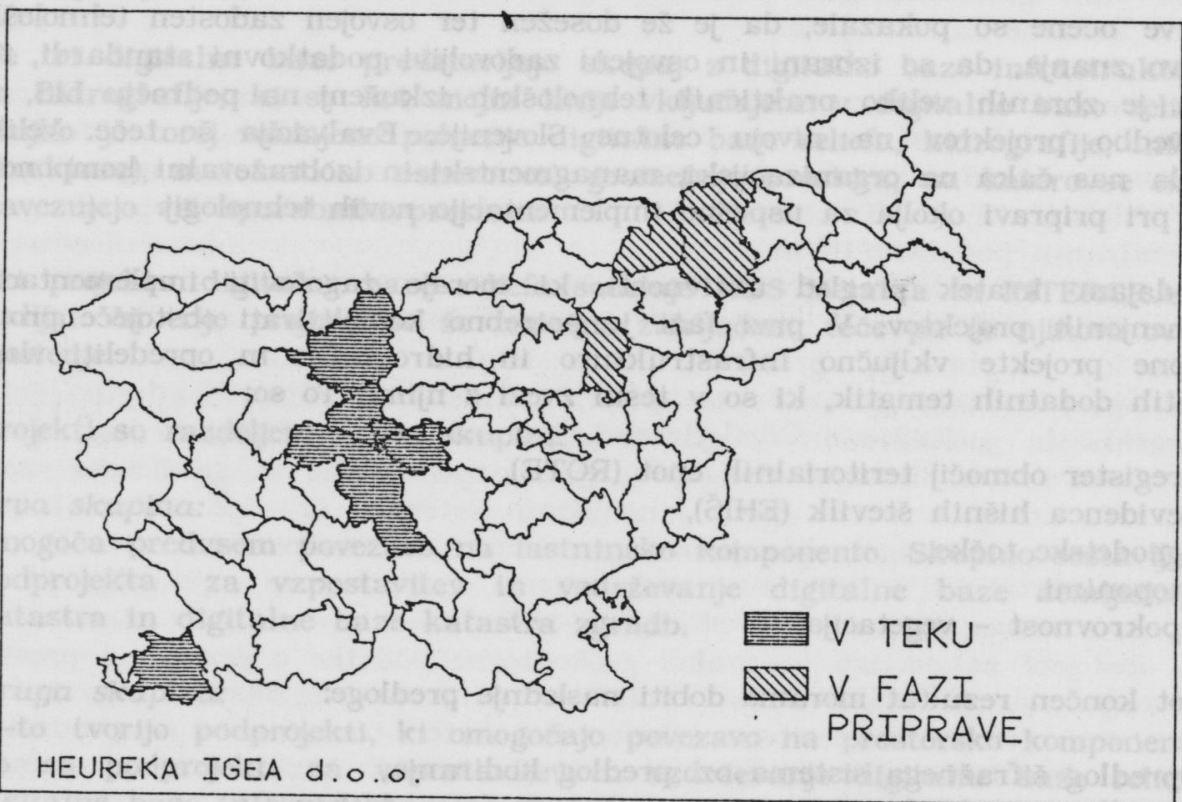

